\title{
Hadith as Adab: Ibn Qutayba's Chapter on Hadith in His 'Uyūn al-Akhbār
}

\author{
Geert Jan van Gelder
}

Ibn Qutayba (d. 276/889) ${ }^{1}$ was a versatile religious scholar ('álim) as well as a man of letters (adīb), who wrote seminal and voluminous works on religious and literary topics. His main books on Hadith, ${ }^{2}$ Ta'wïl mukhtalif al-hadïth and Gharib al-hadith, are standard works in the field. Here, however, I will deal with his main work in the field of $a d a b$, indeed a seminal work of adab: his 'Uyūnal$a k h b \bar{a} r$. This is a kind of literary anthology, characterised by Gérard Lecomte as "a large compendium of $a d a b$, on a number of apparently secular subjects". It is true that these subjects are mainly secular, but the word "apparently" suggests that the book also contains non-secular material. And indeed, religion is by no means absent and is in fact apparent enough to any casual glance; one can safely say that none of its ten main parts, or "books", is devoid of religious topics. The fifth of these is entitled Kitāb al-ilm wa-l-bayān. Bayān, "clear exposition", refers to eloquence and fine style; the section on bayan deals with poetry and speeches, many of the latter being religious sermons. The preceding section on 'ilm is about "knowledge", with quotations from Plato, Hippocrates, Christ, Indian and Persian sages, and Muslim worthies such as 'Umar b. al-Khațāb (d. 23/644); there follow brief chapters on the Qurān, on Hadith, on speculative theology (kalām) and heresy, after which Book Five continues with matters of language and style. But as one can expect in $a d a b$ anthologies there is no sustained discussion, merely a string of anecdotes and sayings, interspersed with poetry.

1 The cut-off date for the theme of the present volume is $250 \mathrm{AH}$; Ibn Qutayba, who was born in 213/828, may have composed his 'Uyün al-akhbār some years after 250/864, but all the material he quotes predates this date. On him see e.g. Gérard Lecomte, "Ibn Kutayba," in Encylopaedia of Islam, znd ed., eds. P.J. Bearman, Th. Bianquis, C.E. Bosworth, E. van Donzel and W.P. Heinrichs (Leiden: Brill, 1971), 3:844-847; Joseph E. Lowry, "Ibn Qutaybah," in Arabic Literary Culture, 500-925, eds. Michael Cooperson and Shawkat M. Toorawa (Detroit: Thomson Gale, 2005), 172-183.

2 I write "Hadith", with capital, for the corpus of traditions as a whole, and "hadith" for an individual tradition. 
It seems appropriate to honour the memory of Gautier (or Gual, as he was known to Dutch colleagues and friends) Juynboll with a few words on this brief chapter on Hadith, seven pages in the edition of Cairo 1925-1930. ${ }^{3}$ It contains a number of sayings on Hadith, almost all of them preceded by some form of $i s n a \bar{d}$, and there are ten short poetic quotations, 26 lines in all. The quoted sayings are mostly about Hadith but do not themselves contain Hadith in the strict sense of sayings going back to the Prophet or talking about him. It is difficult to say what Ibn Qutayba's selection criteria were. Generally, he seems to have collected statements that were striking or amusing, but there are also some more puzzling ones. Here is a translation of the beginning of the section: ${ }^{4}$

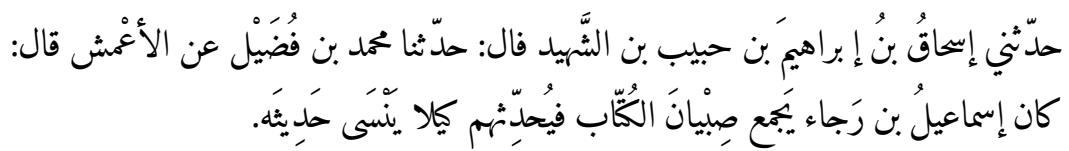

Isḥāq b. Ibrāhīm b. Ḥabīb b. al-Shahīd ${ }^{5}$ told me: Muhammad b. Fuḍayl ${ }^{6}$ told us, on the authority of al-A'mash, ${ }^{7}$ who said: Ismā̄il b. Rajä ${ }^{8}$ used to gather the young boys in the Qurān school (kuttāb) and teach them Hadith, so that he would not forget his Hadith ( fa-yuhaddithuhum kaylā yansā hadìthahu).

What is the point of quoting this saying? Normally the prime reason for teaching is to secure the transmission of knowledge to others, to a younger generation. One is almost tempted to change the vowels given in the edition and read kayläyunsā hadìthuhu, "so that his Hadith would not be forgotten". Young children, after all, have great retentive powers and the young are helpful in Hadith in stretching isnāds, one would think. Religious education, however, began with

3 Ibn Qutayba, 'Uyūn al-akhbār, 4 vols. (Cairo: Dār al-Kutub, 1925-1930), 2:134-140 (the edition used in this article); see also the edition by Mundhir Muhammad Sa'ì̃ Abū Sharr, 4 vols. (Beirut: al-Maktab al-Islāmī, 2008), 2:16o-166.

4 Ibn Qutayba, 'Uyūn, 2:134. Also in al-Basawī (= al-Fasawī), al-Ma'rifa wa-l-tārīkh, ed. Akram Ḍiyā' al-'Umarī, 4 vols. (Medina: Maktabat al-Dār, 1410 AH), 2:610, Ibn Sa'd, Kitāb al-țabaqāt al-kabìr, ed. 'Alī Muḥammad 'Umar, 11 vols. (Cairo: Maktabat al-Khānjī, 2001), 8:435.

5 d. 257/871; see al-Khațīb al-Baghdādī, Tārīkh Madīnat al-Salām, ed. Bashshār 'Awwād Ma'rūf, 17 vols. (Beirut: Dār al-Gharb al-Islāmī, 2001-2006), 7:395-396.

6 d. 195/810-811, see Ibn Qutayba, al-Ma'ārif, ed. Tharwat 'Ukāsha (Cairo: Dar al-Macārif, 1981), 510.

7 d. c. 148/765; see also below, note 13 .

8 Ismāīil b. Rajā̄’ b. Rabī'a al-Zubaydī al-Kūfī, no dates known; see al-Bukhārī, al-Tārīkh al-kabīr, eds. Hāshim al-Nadwī et al., 9 vols. (Hyderabad: Dāirat al-Macārif al-'Uthmāniyya, 1941-1964), 1:353. 
Qur'ān and elementary jurisprudence, not Hadith, for young children were not considered sufficiently reliable as transmitters. ${ }^{9}$ One must assume, then, that the received vowelling is correct and the point of the saying seems to be that Ismā'il b. Rajā's behaviour is unusual, a case of teaching that benefits the teacher more than the taught. Ibn Qutayba, one supposes, found it odd, even amusing: a teacher who teaches primarily in order not to forget, even though his priority should be the transmission of knowledge.

It is immediately followed by another somewhat ambiguous passage:

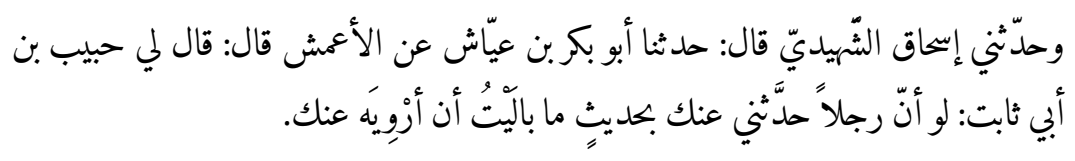

Ishāa al-Shahīdīio told me: Abū Bakr b. 'Ayyāsh' ${ }^{11}$ told us on the authority of al-A'mash, who said: Ḥabīb b. Abī Thābit said to me: If a man told me a hadith on your authority, I would not mind transmitting it on your authority. ${ }^{12}$

- or should we translate $m \bar{a}$ ba alaytu an arwiyahü 'anka as "I would not care to transmit it on your authority", which gives the opposite sense? There is some ambiguity in the verb $b \bar{a} l \bar{a}$, "to care, mind, be concerned". Ibn Qutayba does not comment on this rather odd statement. Al-A'mash is one of the famous Hadith scholars, one of the "readers" of the Qur'ān; ${ }^{13}$ his contemporary Habīb b. Abī Thābit (d. c. 119/737) was a more disputed authority and he is called a mudallis, "a forger". ${ }^{14}$ Assuming that he meant: "I would not mind transmitting it on your authority", he appears to be very casual in his approach to Hadith if with "a man", rajul, he means "any man". Surely this is not how a serious traditionist should proceed. This, however, is not the point here. I think the anecdote is supposed to be funny; it is a joke. For why would Habīb need this intermediary person in the first place if he can have it directly from al-A'mash himself?

\footnotetext{
$9 \quad$ I am grateful to Professor Christopher Melchert for pointing this out to me.

10 He is Isḥāq b. Ibrāhīm b. al-Shahīd, see above, note 5 .

11 d. 193/8o9, see Ibn Qutayba, Ma'āirif, $5 \circ 9$.

12 Ibn Qutayba, 'Uyūn, 2:134.

13 Gautier H.A. Juynboll, "al-A'mash," in Encyclopaedia of Islam THREE, accessed 21 September 2016, http://ezproxy-prd.bodleian.ox.ac.uk:2066/10.1163/1573-3912_ei3_COM_22677.

14 Ibrāhīm Sibṭ al-'Ajamī, al-Tabyīn li-asmā’’ al-mudallisīn, ed. Yahyyā Shafĩq (Beirut: Dār alKutub al-'Ilmiyya, 1986), 19-20 (where this saying is quoted). On Ḥabīb see also Ibn Sa'd, Țabaqāt, 8:437-438, al-Bukhārī, al-Tärīkh al-kabìr, 2:313-314.
} 
Moving on to what follows we find:

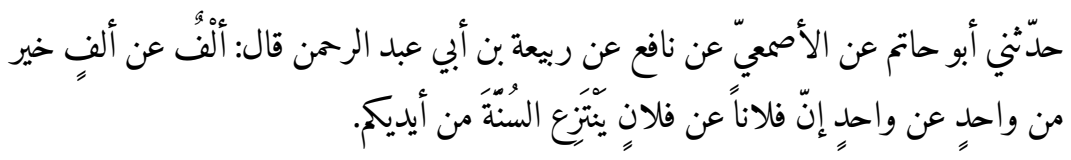

Abū Hātim ${ }^{15}$ told me on the authority of al-Așmaci ${ }^{16}$ on the authority of Nāfi ${ }^{17}$ on the authority of Rabī'a b. Abī 'Abd al-Raḥmān, ${ }^{18}$ who said: One thousand on the authority of one thousand is better that one on the authority of one. "So-and-so on the authority of So-and-so" snatches the Sunna from your hands. ${ }^{19}$

This seems clear: the hadiths called mutawātir are better, in principle, than those termed fard or $\bar{a} h \bar{a} d .{ }^{20}$ This is not particularly interesting and the reason for quoting this is perhaps the vivid expression "snatches the Sunna from your hands" (yantazi'u al-sunnata min aydīkum). An amusing bit is about Suhayl b. Abī Ṣālị̣ (d. 138/755), ,1 who transmitted a hadith about the Prophet Muhammad to Rabī'a b. Abī 'Abd al-Raḥmān (d. 136/753). When, after some time, the latter reminds Suhayl of this, he has no recollection of it. And afterwards he happily continues to transmit the hadith on the authority of Rabía, putting himself in the middle of the isnād, something like "A told me that I told him that B told him ...". ${ }^{22}$ I do not know how such a peculiar up-and-down-andup-again can be depicted in one of Juynboll's spidery webs.

\footnotetext{
15 Abū Ḥātim al-Sijistānī (d. 255/869), philologist.

16 'Abd al-Malik b. Qurayb al-Așma'ì (d. c. 213/828), famous philologist.

17 Nāfi' (d. between 117/735 and 120/738), mawlā of 'Umar b. al-Khațțāb; major transmitter of Hadith.

18 An early legal scholar ( faqīh), known as Rabī'ah al-Ra’y; see e.g. Ibn Qutayba, Ma ārif, 496, Ibn Khallikān, Wafayāt al-'ayānn, ed. Iḥsān 'Abbās, 8 vols. (Beirut: Dār al-Thaqāfa, 19681972), 2:288-29o.

19 Ibn Qutayba, 'Uyūn, 2:134; Ibn 'Abd Rabbih, al-'Tqd al-farīd, eds. Aḥmad Amīn, Aḥmad alZayn and Ibrāhīm al-Ibyārī, 7 vols. (Cairo, 1948-1953, repr. Beirut: Dār al-Kitāb al-'Arabī, 1983), 2:237; al-Qāḍī 'Iyāẹ, Tartīb al-madārikwa-taqrīb al-masālik, eds. Muhammad b. Tāwīt al-Ṭanjī et al., 8 vols. (Rabat: Wizārat al-Awqāf, 1983), 1:46.

20 It seems that judging the value of a hadith on the basis of its isnād became dominant only after the first two centuries; see Christopher Melchert's contribution to the present volume.

21 On him see e.g. al-Ṣafadī, al-Wāfì bi-l-Wafayāt / Das biographische Lexikon des Ṣalāhaddīn Halïl ibn Aibak aș-Ṣafadī, 30 vols. (Beirut-Wiesbaden-Berlin: Franz Steiner-Klaus Schwarz, 1931-2005), 16:31-32.

Ibn Qutayba, 'Uyūn, 2:134.
} 
So far we have been able to discover at least some indications why Ibn Qutayba included a particular saying or anecdote. This short paper cannot discuss all the individual quotations and I should confess that there are some where I am unable to see the point. What to make, for instance, of the one that follows:

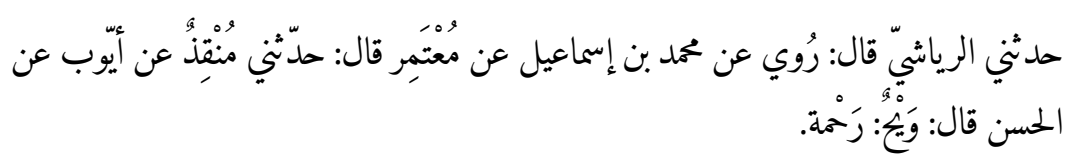

Al-Riyāshi ${ }^{23}$ told me: It is transmitted on the authority of Muhammad b. Ismā'il, on the authority of Mu'tamir: ${ }^{24}$ Munqidh told me on the authority of Ayyūb, on the authority of al-Hasan, who said: Wayh: rahma. ${ }^{25}$

— meaning something like “'Woe!' means 'Pity!" This force of the interjection wayh is confirmed by the lexicographers. But it is not immediately clear why this should be mentioned here; it is not a saying of the prophet Muhammad, the word wayh does not occur in the Quraan, and the quotation is not funny, apart perhaps from being one of the shortest statements introduced by a weighty isna $\bar{d}$. It is apparently inspired by a hadith, not quoted here, in which the Prophet says "Wayḥa 'Ammārr!", upon seeing 'Ammār ibn Yāsir'² exerting himself in building a mosque. ${ }^{27}$ Obviously, he means "Poor 'Ammār!" rather than "Woe to 'Ammār!"

Some items are about the teaching of Hadith. When Qatāda ${ }^{28}$ had taught a good hadith (idha haddatha bi-l-hadithi al-jayyid) he would leave and tell another one the next day (dhahaba yajīu bi-l-thānī ghudwatan), ${ }^{29}$ apparently

23 Presumably the philologist Abū al-Faḍl 'Abbās b. al-Faraj al-Riyāshī (d. 257/871). Some of the following persons named in the isnād have not been identified with certainty.

24 Mu'tamir b. Sulaym b. Țarkhān, d. 187/803, see al-Dhahabī, Siyar a'tām al-nubalā’, eds. Shu'ayb al-Arna'ūṭ et al., 25 vols. (Beirut: Mu’assasat al-Risāla, 1981-1988), 8:477-479.

25 Ibn Qutayba, 'Uyūn, 2:134; Ibn Qutayba, Ta'wīl mukhtalif al-Hadīth, ed. Muḥammad Muhȳì al-Dīn al-Aṣfar (Beirut, 1999), 131 (as wayh kalimat raḥma); Ibn Ḥibban, al-Thiqāt, 9 vols. (Hyderabad, AH 1393), 9:197 (I owe this reference to Professor Christopher Melchert).

26 'Ammār b. Yāsir (d. 37/657 at the Battle of Șiffin), a companion of the prophet Muhammad and later a partisan of 'Alī.

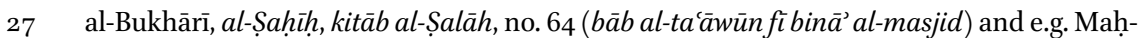
mūd b. 'Umar al-Zamakhsharī, al-Fä̀iq fì gharīb al-Hadīth, eds. Muhammad Abū al-Faḍl Ibrāhīm and 'Alī Muhạmmad al-Bijāwī, 4 vols. (Cairo: Dār al-Fikr, 1993), 4:85.

28 Abū al-Khațțāb Qatāda b. Dicāma al-Sadūsī (d. c. 117/735), see Charles Pellat, "Katāda b. Di'āma," in Encyclopaedia of Islam, 2nd ed. (Leiden: Brill, 1978), 4:748.

29 Ibn Qutayba, 'Uyūn, 2:134. 
to let the first one sink in properly. This is followed by a saying by Shu'ba ${ }^{30}$ on the kinds of people whose Hadith should not be accepted (yutraku hadithuhu) and another by Mālik, ${ }^{31}$ on the four kinds of people whose knowledge ( $\mathrm{ilm}$ ) cannot be accepted. They are sensible sayings, as can be expected: the categories include unreliable, or stupid, or biased people.

There is a report about al-Ḥasan, i.e., al-Ḥasan al-Bașrī (d. 110/728), who would transmit a hadith one day, and repeat it the following day with some additions or omissions but the sense being the same (yazidu fihi wa-yanqușu illa anna al-ma'nā wăhid). ${ }^{32}$ This is followed, as if by way of justification, by a saying by Ḥudhayfa ibn al-Yamān:33 "We are Arabs, who may change the order (nuqaddimu wa-nu'akhkhiru), add things to it or reduce it, without intending to tell lies". ${ }^{34}$ Then we read:

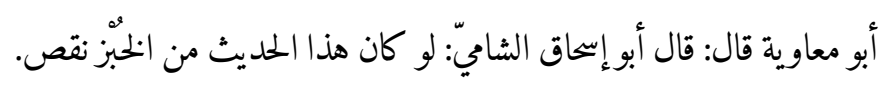

Abū Mucāwiya ${ }^{35}$ said: Abū Isḥāq al-Shāmīin said: "If this Hadith were bread it would be insufficient."

I am not sure what this means; is he speaking of a particular hadith or does hädhà al-hadith mean "this Hadith", meaning the whole corpus? Is there a connection, apart from the use of the verb naqașa, "to reduce" or "to be insufficient", with the sayings of al-Ḥasan and Hudhayfa? Perhaps one should translate "... it would diminish", meaning that if Hadith were edible it would be depleted, whereas in fact it is not and cannot—or should not—be reduced or diminished. Without any commentary on the part of Ibn Qutayba a saying follows that condemns, if not Hadith, then all its transmitters:

30 Shu'ba b. al-Hajjāj (d. 16o/776), scholar and collector of Hadith; see Juynboll's entry on him in Encyclopaedia of Islam, (Leiden: Brill, 1997), 9:491-492.

31 Presumably Mālik b. Anas (d. 179/796), the famous jurist who gave his name to the Mālikī school of jurisprudence.

32 Ibn Qutayba, 'Uyūn, 2:136.

33 Abū 'Abd Allāh Ḥudayfa b. al-Yamān al-'Absī (d. 36/656), a companion of the prophet Muhammad.

34 Ibn Qutayba, 'Uyūn, 2:136.

35 Not identified.

36 I have not found this name in the standard Arabic sources and it is clearly an error. The edition by Abū Sharr has, probably more correctly, Abū Ishāq al-Shaybānī. In Ibn Qutayba, Ma âriff, 451, Abū Isḥāq al-Shaybānī Sulaymān b. Abī Sulaymān, said to have died in $129 / 746-747$, is credited with the same saying but with al-khayr ("the good") instead of $a l-k h u b z$. This is clearly based on a misreading (the two words differ only in their diacritic dots); it does not make more sense and is less interesting than the version of 'Uyün. 


\section{أبو أسامة قال: قال مسعَر: من أبغضني جُعله اللّهُ محدّاً.}

Abū Usāma ${ }^{37}$ said: Mis`ar said: May God make everyone who hates me a muhaddith!38

The point is, of course, that this Mis`ar b. Kidām (d. 155/771-772) ${ }^{39}$ was himself a transmitter of Hadith. Perhaps Mis'ar hints at the poverty of the average Hadith scholar, ${ }^{40}$ and the preceding quotation also suggests that being a transmitter of Hadith does not pay for one's daily bread. The theme of Hadith as bread is then taken up again in a saying by al-A'mash:41

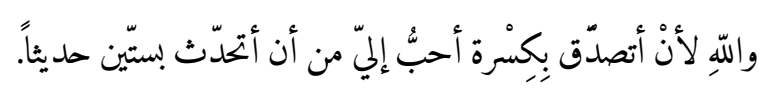

By God, if I gave a bite of bread (kisra) as alms that would be better than transmitting sixty hadiths.

And the famous traditionist Sufyān ibn 'Uyayna ${ }^{42}$ is quoted as saying: ${ }^{43}$

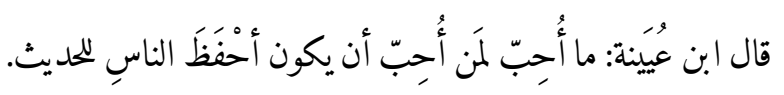

I would not like someone I like to be the one who has memorised most hadiths of all people.

Again, famous muhaddithūn belittle the value of their own field of expertise. Such paradoxes are typical of $a d a b$. One is free to take them at face value or not, and to make of them what one likes. Our compiler, Ibn Qutayba, remains silent in the background.

Hadith experts are not above joking. Once, al-A'mash was asked about the isnād of a certain hadith by the much younger Hafṣ b. Ghiyāth (d. c. 194/8og). ${ }^{44}$

37 Identification uncertain.

38 Ibn Qutayba, 'Uyūn, 2:136; also Ibn Qutayba, Ma'āirif, 481.

39 Thus al-Ṣafadī, Wäfĭ, 25:493; cf. Ibn Qutayba, Ma'ärif, 481 where he is said to have died in $152 / 769$ and his father's name is vowelled as Kudām.

40 A suggestion made at the conference by Professor Houari Touati.

41 Ibn Qutayba, 'Uyūn, 2:136.

42 On Sufyān b. 'Uyayna (107-196/725-811) see Susan A. Spectorsky, "Sufyān b. 'Uyayna," in Encyclopaedia of Islam, 2nd ed. (Leiden: Brill, 1997), 9:772.

43 Ibn Qutayba, 'Uyūn, 2:137.

44 On him, see Ibn Qutayba, Måărif, 510, al-Șafadī, Wäfı̀, 13:98-99. 
Thereupon al-A'mash took Ḥafș by the throat, pushed him (asnadahū) against a wall and said, "This is its isnād!" 45 A similar punning with technical terms is displayed by Ibn al-Sammāk, ${ }^{46}$ who was asked the same question about an isnād and replied, "It is one of al-mursalāt 'urfā (the loosed ones in succession)!"47 He is quoting the beginning of the 77th sura, entitled al-Mursalät (translated as The Loosed Ones by Arberry), which is about winds, but he alludes, of course, to the kind of hadith called mursal, i.e., with an isnād that does not go back all the way to a companion of the prophet Muhammad but only to the next generation.

These slightly irreverent sayings and anecdotes are offset by others that stress the status and importance of Hadith. Al-A'mash again: "When I see an old man who does not seek figh [which here I take to mean 'religious knowledge'] I would like to box his ears (ahbabtu an asfa'ahu)"; ${ }^{\prime 4}$ he also said, "But for learning all those hadiths I would be like any Kufan greengrocer."

Several times the prose gives way to short poems. The great philologist alAșma'ĩ laments the death of Sufyān b. 'Uyayna in eight lines, beginning:49
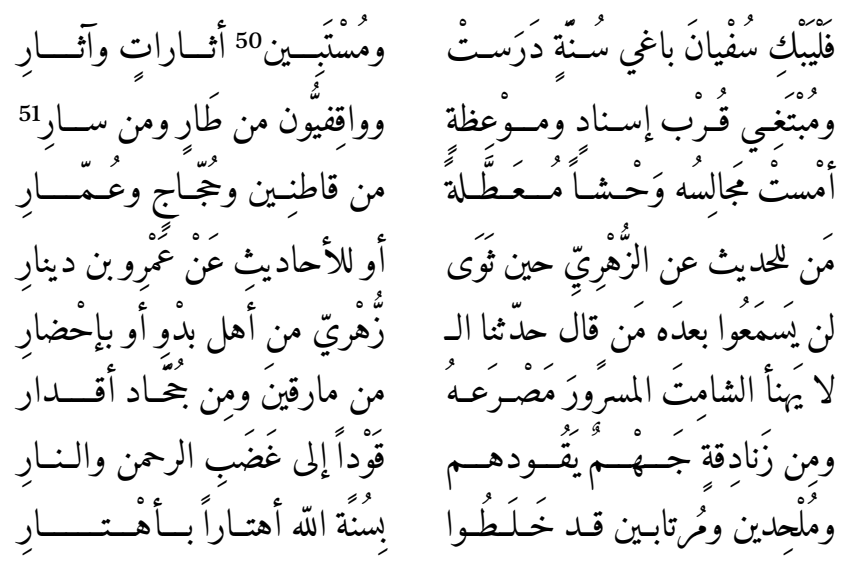

45 Ibn Qutayba, 'Uyūn, 2:137.

46 Abū al-'Abbās Muhammad b. Șabīḥ b. al-Sammāk (d. 183/799), see al-Khațīb al-Baghdādī, Tārīkh Madīnat al-Salām, 3:347-354.

47 Ibn Qutayba, 'Uyūn, 2:137.

48 Ibn Qutayba, 2:137.

49 Ibn Qutayba, 2:135; also al-Dhahabī, Siyar, 8:474-475.

50 Thus in al-Dhahabī, Siyar, rather than mustabìtu as in 'Uyūn.

$5^{1} \quad$ Thus in al-Dhahabī, Siyar, rather than wa-afaqiyyūna min tậrin wa-min țārū as in 'Uyūn (both editions), which is obviously corrupt. 
fa-l-yabki Sufyāna bāghī sunnatin darasat wa-mustabìnu athārātin wa-āthārì wa-mubtaghī qurba isnādin wa-maw'izatin wa-wāqifyyūna min țārin wa-min sārī amsat majālisuhü waḩshan mu'ațtalatan min qāținina wa-ḥujjājin wa-ummārī man li-l-hadìthi 'ani l-Zuhriyyi hìna thawā aw li-l-ahàä̀thi 'an 'Amri bni Dōnārì lan yasma ū ba'dahū man qāla haddathanā l-Zuhriyyu min ahli badwin aw bi-ihḍārì lā yahna'i l-shāmitu l-masrūru mașra'ahū min māriqīna wa-min juḥ̣̂ādi aqdārī wa-min zanādiqatin Jahmun yaqūduhumū qawdan ilā ghadabi l-Raḥmāni wa-l-nārī wa-mulhidīna wa-murtābina qad khalațū bi-sunnati llāhi ahtāran bi-ahtārī

Let Sufyān be lamented by those who desire (to know) a sunna that has fallen into abeyance or who seek the explanation of what remains of past reports, By those desiring a close $i s n \bar{a} d$ and an admonition and those of the clan of Wāqif,52 those who come and go.

The places where he sat teaching are now desolate, deserted of dwellers, of those who come for the hajj or the lesser pilgrimage. Who will transmit Hadith from al-Zuhri ${ }^{53}$ now that he rests in the earth, or the hadiths from 'Amr ibn Dīnār? ${ }^{54}$

Now that he is gone people, whether Bedouin or town dweller, will no longer hear anyone saying "Al-Zuhrī told us ..." May his death not gladden any happy gloater from among the rebels and those who deny the divine ordainments,

$5^{2}$ The Banū Wāqif were a clan of the tribe of Aws; Sufyān's grandfather was a mawlā of a woman of the Banū Hilāl b. Umayya b. Wāqif.

53 Abū Bakr Muhammad b. Shihāb al-Zuhrī (d. 124/742), "one of the founders of Islamic tradition" (Michael Lecker, "al-Zuhrī, Ibn Shihāb," in Encyclopaedia of Islam, nnd ed. (Leiden: Brill, 1960), 1:565).

54 'Amr b. Dīnār (d. 126/744), religious scholar and traditionist, teacher of Sufyān b. 'Uyayna; see Harald Motzki, "Amr b. Dīnār," in Encyclopaedia of Islam THREE, accessed 21 September 2016, http://dx.doi.org/10.1163/1573-3912_ei3_COM_22955. 
Or from the heretics led by Jahm ${ }^{55}$

to the Merciful's wrath and to hellfire,

Or from unbelievers and those who doubt, who mix

God's Sunna with falsehood upon falsehood.

It is not great poetry but it fits in the chapter well. The poet Ibn Munādhir, ${ }^{56}$ who also dabbled in Hadith, saw fit to give advice in verse on whom to trust in matters of Hadith: ${ }^{57}$
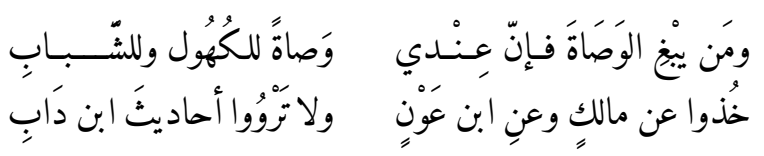

wa-man yabghi l-wașāta fa-inna 'indī wașātan li-l-kuhūliwa-li-l-shabābì

khudhū 'an Mālikin wa-'ani bni 'Awnin wa-lā tarwū aḥādìtha bni Dābì

Whoever wants good advice: I've got it, for mature men and for youths.

Take from Mālik and from Ibn 'Awn, ${ }^{58}$ but do not transmit the hadiths of Ibn Da'b.

Ibn Da’b is Abū al-Walīd 'Īsā b. Yazīd b. Da’b (d. 171/787), of whom Charles Pellat writes that "In the field of the transmission of hadiths (...) Ibn Da'b was not very highly thought of"; some accused him of inventing them. ${ }^{59}$ Ibn Qutayba does not quote the verses that follow in a longer version, ${ }^{60}$ which mentions "false hadiths", ahāaith kidhāb, that are "followed by those who go astray", a phrase

55 Jahm b. Șafwān (executed 128/764), alleged founder of a sect that held "an extreme form of the doctrine of djabr", i.e., predestination (William Montgomery Watt, "Djahmiyya," in Encyclopaedia of Islam, (Leiden: Brill, 1965), 2:389).

56 Muhammad b. Munādhir (d. 198/814), see Fuat Sezgin, Geschichte des arabischen Schrifttums. Band II: Poesie bis ca. 430 H. (Leiden: Brill, 1975), 505-506. Pious when young, he became dissolute in later life; see Ibn Qutayba, al-Shi'rwa-l-shu'arä', ed. Ahmad Muhammad Shākir (Cairo: Dār al-Ma'ārif, 1966-1967), 869 and many anecdotes in Abū al-Faraj al-Ișfahānī, al-Aghānī, 24 vols. (Cairo: Dār al-Kutub—al-Hay’a al-Mișriyya al-Āmma, 19271974), 18:169-210.

57 Ibn Qutayba, 'Uyūn, 2:138-139; cf. Ibn 'Abd Rabbih, 'Iqd, 2:237-238.

$5^{8}$ Mālik is probably Mālik b. Anas (d. 179/796), Ibn 'Awn is 'Abd Allāh b. 'Awn (d. 151/768), see e.g. al-Ṣafadī, Wāfi, 17:389-39o.

59 Charles Pellat, "Ibn Da’b," in Encyclopaedia of Islam, 2nd ed. (Leiden: Brill 1971), 3:742.

6o al-Iṣfahāni, Aghānī, 18:198; Muhammad b. Imrān al-Marzubānī, Nūr al-qabas, al-mukhta-

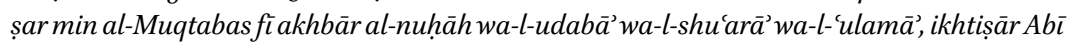


that is taken from the famous Qur'ānic verse about poets (al-Shu'arā' 26:224). In Kitab al-Aghānī it is said that Ibn Munādhir composed the lines having heard that Ibn Da'b had said bad things about him. The point of quoting these lines is perhaps the fact that Muhammad b. al-Munādhir was himself considered unreliable: "Yahyā b. Maīn rejected his transmission, saying, 'He knows about poetry, not about Hadith'".61 It is not unlikely that Ibn Qutayba was aware of this and expected his readers to know.

Since poetry can accommodate anything, why cannot Hadith be versified? Ibn Qutayba quotes two lines by Abū Nuwās, who was, after all, well-versed in Hadith and even seems to have taught it:62
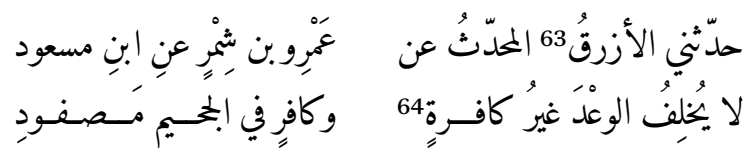

\author{
haddathanī l-Azraqul-muhaddithu 'an \\ 'Amri bni Shimrin 'ani bni Mas'ūdī \\ lāyukhlifu l-wa'da ghayru kāfiratin \\ wa-kāfirin fì l-jahìmi maşüdì
}

\begin{abstract}
Al-Azraq, the muhaddith, told me, on the authority of
'Amr ibn Shimr, ${ }^{65}$ on the authority of Ibn Mas'ūd:66
\end{abstract}

l-Maḥāsin Yūsuf ibn Maḥmūd al-Yaghmūrī / Die Gelehrtenbiographien des Abū 'Ubaidallāh al-Marzubānīin der Rezension des Hāfiz al-Yag̈mūrī, Teil I, ed. Rudolf Sellheim (Wiesbaden: Franz Steiner, 1964), 311.

61 al-Ṣafadī, Wāfì, 5:64; cf. al-Iṣfahāni, Aghānī, 18:208-209.

62 Ibn Qutayba, 'Uyūn, 2:140; Abū Nuwās, Dīwān, eds. Ewald Wagner and Gregor Schoeler, 7 vols. (Wiesbaden-Cairo: Franz Steiner and Berlin-Beirut: Klaus Schwarz, 1958-2006), 5:238; with accompanying anecdote, al-Marzubānī, Nūr al-qabas, 201-202, al-Sahmī alJurjānī, Tārīkh Jurjān, ed. Muḥammad 'Abd al-Mu'īd Khān (Beirut: 'Ālam al-Kutub, 1987), 511-512, and Ibn Manẓūr, Akhbār Abī Nuwās, eds. 'Abbās al-Shirbīnī and Muḥammad 'Abd al-Rasūl Ibrāhīm (Cairo: Maṭba'at al-I'timād, 1924), 1:151-152; attributed to an unnamed muhaddith who was in love with a youth in Abū Manșūr 'Abd al-Malik b. Muhammad alThaāāibī, Khāṣs al-khāṣṣ (Beirut: Dār Maktabat al-Ḥayāt, n.d.), 7o. On the poet's knowledge of Hadith see Ewald Wagner, Abū Nuwās: Eine Studie zur arabischen Literatur der frühen 'Abbāsidenzeit (Wiesbaden: Franz Steiner, 1965), 33-38.

63 Abū Nuwās, Dīwān: al-A'mashu.

64 Ibn Qutayba, 'Uyūn (both editions) has kāfirihī; all other sources have kāfiratin; Abū Nuwās, Dìwān: lā yadkhulu l-nāra ghayru kāfiratin.

65 Abū 'Abd Allāh 'Amr b. Shimr (or Shamir) al-Ju'fī (d. c. 16o/776), see al-Ṣafadī, Wāfí, 23:241.

66 He is the famous companion of the prophet Muhammad, 'Abd Allāh b. Mas'ūd (d. 32/652653), see Jean-Claude Vadet, “Ibn Mas'ūd," in Encyclopaedia of Islam, 2nd ed. (Leiden: Brill, 
Only an unbelieving woman breaks her promise, or an unbelieving man, who will be fettered in Hellfire.

The longer, four- or five-line version found in the Diwwan and elsewhere shows that the lines are addressed to a youth who had apparently broken his promise to his lover. Al-Azraq is Isḥāq b. Yūsuf al-Azraq al-Wāsițī (d. 195/810-811), ${ }^{67}$ and in the anecdote that accompanies the lines in several sources he emphatically denies that he had told Abū Nuwās anything like it. Abū Nuwās actually composed a series of such poems, found in his Diwān in a special subsection of his mujūn or "libertine" poetry and entitled his "musnadāt" or "isnād poems".68 They are all unserious and a few of them are obscene. Ibn Qutayba does not quote them. He was not a prude and in his preface to Uyūn al-akhbār he explains that quoting obscenities may be justified. ${ }^{69} \mathrm{He}$ did, however, not do so in sensitive contexts involving religious matters, something that he condemns in al-Jāhịiz.

Ibn Qutayba then drifts away from Hadith, for the following anecdote, with an epigram by Musāwir al-Warrāq and its riposte by someone else, is more about figh and the use of qiy $\bar{a} s .{ }^{70}$ The chapter ends with a joke. ${ }^{71} \mathrm{~A}$ man hears someone cry out: "Who can find for me an old man who has lost his way (shaykh dalla)?" He then takes the searcher to Bishr al-Marīsi $\overline{\mathbf{I}}^{22}$ and says, "Here is an erring old man (shaykh dâall), take him!" This Bishr, as Ibn Qutayba adds, believed in the createdness of the Qurān, a hotly debated issue, which by Ibn Qutayba's time had become an unorthodox position. Again, this concluding anecdote has nothing to do with the topic of Hadith, but it provides at least a seamless transition to the next chapter, on deviant theological opinions (alahwä̀wa-l-kalām fìal-dìn).

As so often in adab, the section offers a medley of hazl and jidd, jesting and seriousness. It has little or no structure, the items being strung together at most associatively and virtually without commentary. Just as in Hadith itself, one

1971), 3:873-875. The isnād is not only fictitious but incomplete, in view of the time gap between the last two names.

67 al-Bukhārī, al-Tārīkh al-kabīr, 1:406.

68 Abū Nuwās, Dīwān, 5:237-247.

69 Ibn Qutayba, 'Uyūn, 1: Preface, lām-mìm.

70 Ibn Qutayba, 'Uyūn, 2:140; see Geert Jan van Gelder, "Musāwir al-Warrāq and the Beginnings of Arabic Gastronomic Poetry," Journal of Semitic Studies 36 (1991): 309-327, esp. 315.

71 Ibn Qutayba, 'Uyūn, 2:140.

72 Abū 'Abd al-Raḥmān Bishr b. Ghiyāth al-Marīsī (d. 218/833), a prominent Murji'ite theologian; see Carra de Vaux, A.N. Nader, and J. Schacht, "Bishr b. Ghiyāth al-Marīisī, in Encyclopaedia of Islam, 2nd ed. (Leiden: Brill, 1960), 1:1241-1242. 
often has to read between the lines, hoping one guesses right. System and consistency are not to be expected and perhaps not even desirable in this genre. One could speak of the "molecularity" of $a d a b$, a term that used to be applied to classical Arabic poetry but is perhaps more suitable for the kind of adab of which Ibn Qutayba was a pioneer.

\section{Bibliography}

Abū Nuwās. Dīwān. Edited by Ewald Wagner and Gregor Schoeler. 7 vols. WiesbadenCairo: Franz Steiner and Berlin-Beirut: Klaus Schwarz, 1958-2006.

al-Basawī (= al-Fasawī). Al-Márifa wa-l-tārîkh. Edited by Akram Diyā̄a al-'Umarī. 4 vols. Medina: Maktabat al-Dār, AH 1410.

al-Bukhārī. Al-Tärīkh al-kabìr. Edited by Hāshim al-Nadwī et al. 9 vols. Hyderabad: Dāirat al-Maārif al-'Uthmāniyya, 1941-1964.

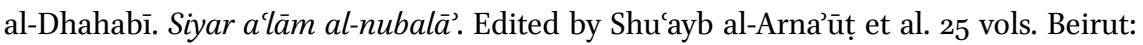
Mu’assasat al-Risāla, 1981-1988.

Gelder, Geert Jan van. "Musāwir al-Warrāq and the Beginnings of Arabic Gastronomic Poetry." Journal of Semitic Studies 36 (1991): 309-327.

Ibn 'Abd Rabbih. Al-Iqd al-farīd. Edited by Aḥmad Amīn, Aḥmad al-Zayn and Ibrāhīm al-Ibyārī. 7 vols. Cairo, 1948-1953. Repr. Beirut: Dār al-Kitāb al-'Arabī, 1983.

Ibn Ḥibbān. Al-Thiqāt. 9 vols. Hyderabad: Dāiirat al-Ma'ārif al-'Uthmāniyya, AH1393.

Ibn Khallikān. Wafayāt al-'ayān. Edited by Iḥsān 'Abbās. 8 vols. Beirut: Dār al-Thaqāfa, 1968-1972.

Ibn Manzūur. Akhbār Abī Nuwwās. Edited by 'Abbās al-Shirbīnī and Muhammad 'Abd alRasūl Ibrāhīm. Vol. ı. Cairo: Maṭba'at al-I'timād, 1924.

Ibn Qutayba. Al-Ma'ārif. Edited by Tharwat 'Ukāsha. Cairo: Dar al-Ma'ārif, 1981.

Ibn Qutayba. Al-Shi'r wa-l-shu'arä̉. Edited by Ahmad Muhammad Shākir. Cairo: Dār al-Ma'ārif, 1966-1967.

Ibn Qutayba. Ta’wīl mukhtalif al-Hadīth. Edited by Muhammad Muhyī al-Din al-Aṣfar. Beirut: al-Maktab al-Islāmī, 1999.

Ibn Qutayba. 'Uyūn al-akhbār. 4 vols. Cairo: Dār al-Kutub, 1925-193o.

Ibn Qutayba. 'Uyūn al-akhbār. Edited by Mundhir Muḥammad Saīd Abū Shár. 4 vols. Beirut: al-Maktab al-Islāmī, 2008.

Ibn Sa'd. Kitāb al-țabaqāt al-kabìr. Edited by 'Alī Muhammad 'Umar. 11 vols. Cairo: Maktabat al-Khānjī, 2001.

al-Ișfahān̄ī, Abū al-Faraj. Al-Aghānī. 24 vols. Cairo: Dār al-Kutub—al-Hay’a al-Miṣriyya al-'̄̄mma, 1927-1974.

Juynboll, Gautier H.A. "al-A'mash." In Encyclopaedia of Islam THREE. Edited by Kate Fleet, Gudrun Krämer, Denis Matringe, John Nawas and Everett Rowson. Accessed 
21 September 2016. http://ezproxy-prd.bodleian.ox.ac.uk:2066/10.1163/1573-3912_ei3 _COM_22677.

Juynboll, Gautier H.A. “Shu'ba b. al-Hadjdjādj.” In Encyclopaedia of Islam, 2nd edition. Edited by P. Bearman, Th. Bianquis, C.E. Bosworth, E. van Donzel and W.P. Heinrichs, 9:491-492. Leiden: Brill, 1997.

al-Khațīb al-Baghdādī. Tārīkh Madinat al-Salām [= Tārīkh Baghdād]. Edited by Bashshār 'Awwād Ma'rūf. 17 vols. Beirut: Dār al-Gharb al-Islāmī, 2001-20o6.

Lecker, Michael. "al-Zuhrī, Ibn Shihāb." In Encyclopaedia of Islam, 2nd edition. Edited by P. Bearman, Th. Bianquis, C.E. Bosworth, E. van Donzel and W.P. Heinrichs, 11:565566. Leiden: Brill, 2002.

Lecomte, G. "Ibn Kutayba." In Encyclopaedia of Islam, 2nd edition. Edited by P. Bearman, Th. Bianquis, C.E. Bosworth, E. van Donzel and W.P. Heinrichs, 3:844-847. Leiden: Brill, 1971.

Lowry, Joseph E. "Ibn Qutaybah." In Arabic Literary Culture, 500-925, edited by Michael Cooperson and Shawkat M. Toorawa, 172-183. Detroit: Thomson Gale, 2005 (DLB, 311).

al-Marzubānī, Muḥammad b. 'Imrān. Nūr al-qabas, al-mukhtașar min al-Muqtabas

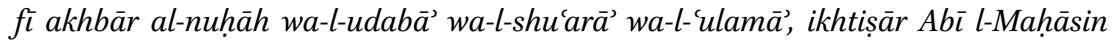
Yūsuf ibn Maḥmūd al-Yaghmūrī / Die Gelehrtenbiographien des Abū 'Ubaidallāh alMarzubānī in der Rezension des Hā̄fiz al-Yaġmūrī, Teil I: Text. Edited by Rudolf Sellheim. Wiesbaden: Franz Steiner, 1964.

Motzki, Harald. "Amr b. Dīnār." In Encyclopaedia of Islam THREE. Edited by Kate Fleet, Gudrun Krämer, Denis Matringe, John Nawas and Everett Rowson. Accessed 21 September 2016. http://dx.doi.org/10.1163/1573-3912_ei3_COM_22955.

Pellat, Charles. "Ibn Da'b." In Encyclopaedia of Islam, 2nd edition. Edited by P. Bearman, Th. Bianquis, C.E. Bosworth, E. van Donzel and W.P. Heinrichs, 3:742. Leiden: Brill, 1971.

Pellat, Charles. "Katāda b. Di'āma." In Encyclopaedia of Islam, 2nd edition. Edited by P. Bearman, Th. Bianquis, C.E. Bosworth, E. van Donzel and W.P. Heinrichs, 4:748. Leiden: Brill, 1978.

al-Qāḍ̄i 'Iyāọ. Tartīb al-madārik wa-taqrib al-masālik. Edited by Muḥammad b. Tāwīt al-Ṭanjī et al. 8 vols. Rabat: Wizārat al-Awqāf, 1983 .

al-Ṣafadī, Șalāḥ al-Dīn Khalīl b. Aybak. Al-Wāfì bi-l-Wafayāt / Das biographische Lexikon des Șalāhaddīn Halīl ibn Aibak aṣ-Ṣafadī. 30 vols. Beirut-Wiesbaden-Berlin: Franz Steiner-Klaus Schwarz, 1931-2005.

al-Sahmī al-Jurjānī. Tārīkh Jurjān. Edited by Muḥammad 'Abd al-Mu'īd Khān. Beirut: 'Ālam al-Kutub, 1987.

Sezgin, Fuat. Geschichte des arabischen Schrifttums. Band II: Poesie bis ca. 430 H. Leiden: Brill, 1975 .

Sibṭ al-'Ajamī, Ibrāhīm. Al-Tabyīn li-asmǟ' al-mudallisìn. Edited by Yahyā Shafīq. Beirut: Dār al-Kutub al-'Ilmiyya, 1986. 
Spectorsky, Susan A. “Sufyān b. 'Uyayna." In Encyclopaedia of Islam, 2nd edition. Edited by P. Bearman, Th. Bianquis, C.E. Bosworth, E. van Donzel and W.P. Heinrichs, 9:772. Leiden: Brill, 1997 .

al-Tha'ālibī, Abū Manșūr 'Abd al-Malik b. Muḥammad. Khāṣṣ al-khāṣṣ. Beirut: Dār Maktabat al-Ḥayāt, n.d.

Vadet, Jean Claude. "Ibn Mas'ūd." In Encyclopaedia of Islam, 2nd edition. Edited by P. Bearman, Th. Bianquis, C.E. Bosworth, E. van Donzel and W.P. Heinrichs, 3:873875. Leiden: Brill, 1971.

Wagner, Ewald. Abū Nuwās: Eine Studie zur arabischen Literatur der frühen 'Abbāsidenzeit. Wiesbaden: Franz Steiner, 1965.

Watt, William Montgomery. “Djahmiyya." In Encyclopaedia of Islam, and edition. Edited by P. Bearman, Th. Bianquis, C.E. Bosworth, E. van Donzel and W.P. Heinrichs, 3:389. Leiden: Brill, 1971.

al-Zamakhsharī, Maḥmūd b. 'Umar. Al-Fāiq fígharīb al-Hadīth. Edited by Muhammad Abū al-Faḍl Ibrāhīm and 'Alī Muḥammad al-Bijāwī. 4 vols. Cairo: Dār al-Fikr, 1993. 